\title{
Understanding the Dynamics of Self-discrepancy Formation of Self- injurious Adolescents: A Case Study of Self-injury
}

\author{
Mubammad Abdul Hadi'; Banyu Wicaksono ${ }^{1}$ \\ ${ }^{1}$ Department of Psychology, Universitas Negeri, \\ ${ }^{1}$ Jl. Colombo No. 1 Karang Malang Sleman, Yogyakarta \\ muhammad0723fip2016@student.uny.ac.id
}

\begin{abstract}
How the self-discrepancy of self-injurious adolescents was formed is yet to be understood clearly. Several studies have clearly stated that self-discrepancy contributes to propel adolescents to injure themselves. This study attempted to understand the dynamics of self-discrepancy formation in the sample of late adolescents who self-injure. This study used a descriptive qualitative research method and case study approach to examine this phenomenon. Data were obtained from six participants, using an open-ended questionnaire, which asks about how self-discrepancy in the participants was formed. Data were analyzed using thematic analysis to identify themes and subthemes that indicate how self-discrepancy was formed. The result showed that ten significant themes emerge in the selfdiscrepancy formation of self-injurious adolescents. Two factors contribute to form selfdiscrepancy among adolescents who self-injure: external dan internal. These factors are achieved from the familial and social interaction that are perceived negatively by the participants. Based on the results of this study, self-discrepancies in adolescent self-injurers should be considered when intervening in self-injurious adolescents.
\end{abstract}

Keywords: Adolescence; self-discrepancy; self-injury

\section{Introduction}

In recent years, self-injury has become acute mental health and clinical problem. It is estimated that more than $20 \%$ of adolescents worldwide have injured themselves intentionally (Wilkinson, 2013). Self-injury must be distinguished from attempted suicide. Self-injury is not intended to end the perpetrator's life but as a strategy to release stress (Martin \& Hack, 2018).

Most of the self-injury was carried out by adolescents (13-21 years). This correlates with Hall's (1904) explanation that adolescents experience a storm and stress phase, with the idea that adolescents are often unable to consider their behaviour rationally. They generally relieve stress by doing problem-focused coping. However, adolescents' self-regulation process starts from diverting negative emotions by doing fun activities or dealing directly with the uncomfortable effects resulting from stress (Ginsburg \& Kinsman, 2014).

The negative possibility is that there are wrong stress-releasing strategies such as smoking, drug abuse, free sex, and selfisolation. This negative behaviour of relieving stress then leads to new problems that are more difficult to overcome. One of them is self-injury, which is considered a negative behaviour in relieving stress. This can be characterized as the emotionfocused coping strategy, in which individuals divert psychological stress by reducing negative emotions (Lazarus \& Folkman, 1984).

Noviekayati \& Mandas (2016) stated that emotion-focused coping significantly correlates with self-injury, especially in the type of escape and avoiding the problem. Shapiro (2008) and Sheehy, Noureen, Khaliq, Dhingra, Husain, Pontin, Cawley, \& Taylor (2019) also state that self-blame is a 
form of emotion-focused coping leads to self-injury.

Regarding the causes of self-injury in general, Loesch (2015) states that the disorder tends to be due to the perpetrator's self-discrepancy. This is because adolescence is an individual phase to align the expected self-concept with the actual self, according to the wishes he or she hopes to attain. When there is a discrepancy between high and unrealistic expectations, followed by failure after failure, the adolescent is assumed to instil selfpunishing behaviour.

At the same time, self-injury is related to disappointment (Martorana, 2015), which stems from self-discrepancy in actual/own versus ideal/own (Higgins, 1987). A person who experiences this discrepancy shows that his or her actual attributes do not match the ideal state that he or she hopes or wishes to attain. This discrepancy leads to disappointment, which is a predictor of self-injury (Reis, Tome, Ramiro, \& Gaspar, 2017).

Self-injury is related to shame (McDonald, O'Brien, \& Jackson, 2007: 302; Martin \& Hack, 2018), which stems from self-discrepancy in actual/own versus ideal/other (Higgins, 1987). A person who experiences this discrepancy shows that his or her actual attributes do not match the ideal state that the person believes some significant other person hopes or wishes that he or she would attain. This discrepancy leads to shame, which is a predictor of self-injury (VanDerhei, Rojahn, Stuewig, \& McKnight, 2013).

Self-injury is also related to fear (Liu, Cheek, \& Nestor, 2016), which stems from self-discrepancy in actual/own versus ought/other (Higgins, 1987). A person who experiences this discrepancy shows that his or her actual attributes do not match the state that the person believes some significant other person considers to be his or her duty or obligation to attain. The emotional impact of this discrepancy is the emergence of fear or a sense of being threatened.

Self-injury is also associated with guilt (McDonald, O’Brien, \& Jackson, 2007), which stems from self-discrepancy between actual/own versus ought/own (Higgins, 1987). A person who experiences this discrepancy shows that their attributes do not match the state that the person believes it is his or her duty or obligation to attain. The discrepancy predicts the person to be vulnerable to guilt, agitated, dan disappointed. The guilt manifested in efforts to punish oneself is the reason for self-injury (Liu, Cheek, \& Nestor, 2016).

Therefore, it is vital to study the selfdiscrepancy of adolescent self-injurers from the perspective of the perpetrators and how self-discrepant they are and how they interpret self-injury. From this study, we will find information regarding contributing factors to self-injury and its relation to selfdiscrepancy. This information can form the basis for psychological intervention, both in the clinical setting and in parental care.

Based on the factors mentioned, this study will answer this research question: "how does self-discrepancy in adolescent self-injurers be formed in terms of four types of self-discrepancy, including the discrepancy between actual/own versus ideal/own, the discrepancy between actual/own versus ideal/other, the discrepancy between actual/own versus ought/own, and the discrepancy between actual/own versus ought/other?"

\section{Methods}

\section{Research Design}

This qualitative exploratory study explores and describes the dynamics of selfdiscrepancy formation in self-injurious adolescents. The study of self-discrepancy and self-injury is an issue that is rarely raised in Indonesia. Since self-injury occurs in marginal groups in Indonesia, it is suitable to use the case study approach (Crowe, 
Cresswell, Robertson, Huby, Avery, \& Sheikh, 2011). Besides, the topic of selfdiscrepancy and self-injury could not be manipulated by researchers, so that it is suitable for the case study that relies on natural contexts.

\section{Participants}

The participants of this study were six adolescent self-injurers who were chosen on a theoretical sample based on the classification of the impulsive self-injury term stated by Simeon and Favazza (2001) and Buresova (2016).

Participants were acquired through the snowball technique because some of the self-injurers imitated their peers. This selfinjury trajectory could be traced to adolescents who were also affected by the same disorder. The following is a summary of all participants in this study:

Table. 1. List of The Participants

\begin{tabular}{|l|l|l|l|}
\hline Pseudonym & Gender/Age & $\begin{array}{l}\text { Adolescence } \\
\text { stage }\end{array}$ & Method \\
\hline P1: Arman & Male/19 & Late adolescence & Face-to-face \\
\hline P2: Desi & Female/21 & Late adolescence & Face-to-face \\
\hline P3: Putri & Female/21 & Late adolescence & Face-to-face \\
\hline P4: Auliya & Female/19 & Late adolescence & Face-to-face \\
\hline P5: Fadil & Male/21 & Late adolescence & Face-to-face \\
\hline P6: Rizki & Female/20 & Late adolescence & Face-to-face \\
\hline
\end{tabular}

Note: $\mathrm{P}=$ Partisipan

\section{Findings and Discussion}

The characteristic of selfdiscrepancy in adolescent self-injurers

Four types of self-discrepancy explain the characteristics of selfdiscrepancy, according to Higgins (1987). The following is the characteristics of selfdiscrepancies based on the four types of it:

A. The characteristics of self-discrepancy between actual/own versus ideal/own

In the self-discrepancy between actual/own versus ideal/own, there are six characteristics of self-discrepancy, including unemployed versus working person, impoverished versus wealthy, closed person versus able to communicate well, difficulty in finding friends versus sociable person, irritable sibling versus patient sibling, and neglected child versus well-cared child. Each of these subthemes is explained as follows:

\section{1) Unemployed versus working person}

The participant has ideal attributes that she or he wants to achieve. When this does not match the current state of his or her, self-discrepancy emerges. In the first characteristic, unemployment versus working person, the participant wants to work and earn money, but the participant is unemployed. This situation causes feelings of sadness and disappointment, which leads to self-injury. Arman told us that:

"I always hope I can work, even though I do not know what kind of work I can do. This jobless situation makes me confused and dizzy all the time" (P1/Arman).

\section{2) Impoverished versus wealthy}

Economic status has a significant influence on an individual's life. A less prosperous participant is more vulnerable to depression. The discrepancy between 
the actual self and the ideal attributes that he or she hopes to attain makes the participant feel sad and confused.

One of the participants, Fadil, openly mentioned that the impoverished condition he experienced strongly influenced his self-injury. When he did not have money, he felt that the other problems are getting heavier because his mind focuses on his deprived conditions.

\section{3) Closed person versus able to communicate well}

The ability to communicate and express opinions or feelings to others is a significant aspect of everyday life. All the participants are characterized as closed persons who have difficulty in expressing their minds. The gap between the ideal self versus the fact that they are closed persons makes participants are vulnerable to sadness and disappointment. Not infrequently, if their negative emotions are held back and cannot be expressed, selfinjury is a way out to vent their emotions. Desi stated that:

"The problem is that if I tell my emotional problem slowly, no one will understand. I cannot tell my family and my friends about my problem. That is why I sometimes burst my emotion out [through self-injury]. No one understands either. I just want to show, you know, this is my annoyance. You know my fault, this is my fault ..." (P2/Desi).

\section{4) Difficulty in finding friends and sociable person}

The communication problem in participants has another negative impact, which makes them have difficulties making friends. Because they cannot convey their opinions and feelings well, they tend to be quiet, which makes them less able to get along with their peers. Arman stated that:

"Because I find it difficult to make friends, I am like being ostracized, shunned. I have no choice but to ignore it. I am not happy like this. I want to have friends, just like others. I want that, but in fact, it does not happen." (P1/Arman)

\section{5) Irritable sibling versus patient sibling}

Fraternal ties are a significant thing according to the perceptions of the participants. For example, Desi felt responsible for her sister's mischief. She is accustomed to scolding her many times, and there is always a rivalry between them. She hopes that she can become more patient with her sister. She thought that she triggered her sibling's rebellious and unruly action. The discrepancy between her actual state as an irritable sister and her ideal self to be a patient sibling makes her vulnerable to sadness and disappointment.

\section{6) Neglected child versus well-cared child}

The participants felt that their parents should pay attention to them. However, they thought that their parents were ignorant and did not care about their situation. When looking at their friends, they compared their neglected situation to them. The participants thought that other parents care so much for their children, not like theirs. The gap between the ideal self versus the actual self makes participants are vulnerable to sadness and disappointment. One of the participants, Putri, stated that:

"My mom and dad are working early in the morning. They came back late at night. Usually, we get together late at night. Automatically during that time, I was at home alone. No friends either. So I was at home alone and no friends to chat with. Then, what can I do? Sometimes I talk to my parents during dinner, but I feel that they did not listen to me at all." (P3/Putri).

B. The characteristic of selfdiscrepancy between actual/own versus ideal/other

In this self-discrepancy, there are two characteristics, including averageintelligent versus intelligent and 
rebellious/disobedient child versus obedient child, which is explained as follows:

\section{Average-intelligent child versus intelligent child}

The participants' parents wanted their children to be intelligent, as evidenced by high academic scores. However, participants only received an average score. This situation creates selfdiscrepancy, caused participants to be vulnerable to sadness, gloom, and disappointment. Desi stated that:

"No one understands me. At home, my mom often beat me for trivial matters like grades. My score is not ten, nine, just go down like that, then she beat me again to push me to study harder" (P2/Desi).

\section{Disobedient/rebellious child versus obedient child}

The dysfunctional family made the participants feel depressed. As a form of protest against overprotective parenting, Arman rebelled against family rules. He also let his hair long, even though he knows that his parents do not like it. Another participant, Putri, also rebelled by running away from home. She was uncomfortable because of familial criticism and hostility that made her dislike both her parents.

"I ran away from home, but my parents did not realize it. Nobody realized. Until my friend told me, 'Come on, just come home, just go home. I did not want to. I did not want to go home. I did not want to be at home." (P3/Putri)

C. The characteristic of selfdiscrepancy between actual/own versus ought/own

In the self-discrepancy between actual/own versus ought/own, there is a characteristic of self-discrepancy, namely disobedient/rebellious child versus obedient child, which is explained as follows:

Disobedient/rebellious child versus obedient child

In this study, the participants felt obliged to obey their parents, but they were not obedient in reality. This situation makes participants feel guilty and agitated. One of the participants, Riski, stated that: "I admit that I am an insolent child, not filial at all [to parents]. But I was so hurt by them, and I do not care anymore" (P6/Rizki).

D. The characteristic of selfdiscrepancy between actual/own versus ought/other

In the self-discrepancy between actual/own versus ought/other, there is a characteristic of self-discrepancy, namely filial piety versus impertinent, which is explained as follows:

\section{Impertinent versus filial piety}

In this study, the participants believe that the significant others want them to be devoted to their parents. However, in reality, the participants neglected their parents. This selfdiscrepancy makes participants are vulnerable to guilt and agitation-related emotions. Desi stated that:

"I hurt myself when my mother was sick because my uncle judged me: You are an insolent child, your parents are sick, but you do not care. What kind of child are you!" (P2/Desi).

The characteristics of selfdiscrepancy in adolescents self-injurer illustrated in the following table: 
Trial Application of Acceptance Afada Alhaque ${ }^{1}$, Poeti Joefiani', Esti Wungu ${ }^{3}$

Table 1. The characteristics of the self-discrepancy on self-injurious adolescents

\begin{tabular}{|l|l|l|}
\hline No & The characteristics of self-discrepancy & \multirow{3}{*}{$\begin{array}{l}\text { The type of self- } \\
\text { discrepancy }\end{array}$} \\
\hline 1 & Unemployed versus working person & \multirow{2}{*}{$\begin{array}{l}\text { Actual self versus } \\
\text { ideal/own }\end{array}$} \\
\hline 2 & Impoverished versus wealthy & \\
\hline 3 & Closed person versus able to communicative well \\
\hline 4 & Difficulty in finding friends and sociable person & $\begin{array}{l}\text { Actual self versus } \\
\text { ideal/other }\end{array}$ \\
\hline 5 & Irritable sibling versus patient sibling & $\begin{array}{l}\text { Actual self versus } \\
\text { ought/own }\end{array}$ \\
\hline 6 & Neglected child versus well-cared child & $\begin{array}{l}\text { Actual self versus } \\
\text { ought/other }\end{array}$ \\
\hline 7 & Average-intelligent child versus intelligent child \\
\hline 8 & Disobedient/rebellious child versus obedient child & Disobedient/rebellious child versus obedient child \\
\hline 9 & Impertinent versus filial piety &
\end{tabular}

Contributing factors in forming self-discrepancy in adolescent selfinjurers.

We found two factors that contributed to the formation of selfdiscrepancy in adolescent self-injurers, including external factors and internal factors, as follows:

\section{A. External Factor}

The external factors that contribute to forming self-discrepancy among adolescent self-injurers consist of four sub-themes, including growing up in a dysfunctional family, the victim of bullying, victims of sexual violence, and being trapped in a toxic relationship.

\section{1) Growing up in a dysfunctional family}

All of the participants in this study grew up in dysfunctional families. This means that the family that is expected to provide warmth, a sense of security, and conducive space for growing up is not experienced by the participants.

In this theme, the dysfunctional families consisted of four sub-themes: low attachment to the parents, low-cohesive family, overprotective parenting style, neglected parenting, and victims of domestic violence.

"Since the age of two months, my mother worked all day and rarely at home. Since then, I lived with my grandparents. My father? I do not know how he looks like. Maybe they divorced since I was not born" (P5 / Fadil).

"They are very protective. Since I was little, I felt uncomfortable. I want to go anywhere, but I cannot. I am always monitored and controlled. I used to think, and maybe it is because I was little. Still underage. Not yet mature. Nevertheless, until now, it is just the same." (P1/Arman).

\section{2) Victim of bullying}

Participants experience bullying that occurs in the school. They experienced bullying since childhood which left a profoundly negative impact on them. One of the participants, Arman, stated that:

"When I passed the school gang, I was teased. If they do not need me, they do not want to talk to me. They don't want to hang out with me. They only come when they need me. For example, on the test, they asked me to do their test. I was told to write in their book. I was asked to buy this, to buy that, to buy cigarettes for the gang leader." (P1/Arman).

\section{3) Victims of sexual violence}

Female participants in this study experienced sexual abuse that made a 
negative impact on their mental health. The sexual violence varied, from unwanted touching and kissing to rape. One of the participants, Putri, stated that: "My uncle was touching mine [vagina]. $\mathrm{He}$ then rubbed it. I remember that, and it did not happen just once or twice. He liked to take me in and did that. Nevertheless, I never told my parent. If I remember now, I am still too little to understand, and I was not aware of it." (P3/Putri).

\section{4) Being trapped in a toxic relationship}

Having a toxic relationship contributes to forming self-discrepancy in adolescent self-injurers. This unhealthy romantic relationship is characterized by emotional turbulence and physical violence. The toxic relationships experienced by the participants consisted of overprotective romantic relationships and dating violence.

" ... my boyfriend limit me to hang out with many friends, especially with boys" (P3/Putri).

"My boyfriend beat me. He beat me with a helmet in front of many people. He burned his cigarettes against my skin. I just realized it was scary"(P4/Auliya).

\section{B. Internal Factor}

The self-discrepancy is also formed due to internal factors that exist within the participants. We divide these internal factors into five themes: selfhatred, negative social comparison, problem in communication, problem in getting along, and loneliness.

\section{1) Self-hatred}

The self-hatred attitude in participants comes from a negative perception that they are not worthy of receiving acceptance from others, a low self-image, and a feeling that they are not valuable. This self-hatred consists of three sub-themes, including low self-image, selfblame, and feel like a failure.
"I failed. I was like a failure. I cannot do anything. My mom always judges me. Whatever I do will always be wrong. It must always be wrong, always. Oh God, you know? I just made coffee. My mother scolded me that the coffee was not good. Even though I made it for my guest, I had good intentions. I got scolded." (P3/Putri).

\section{2) Negative social comparison}

When the participants compare their condition with others, they feel that other people's situations are better than their own. As they were children, they felt not getting enough love and attention from their parents. They felt that their parents ignored them and did not pay enough attention. Therefore, the participant felt that they were unlucky and were born into a faulty family. Auliya told us that:

"I never feel at home. I want to be like other kids. I want to be paid attention by my parents? 'How can regular parents pay attention to their children? How come I don't?' I never asked my parents to bear me like this" (P4/Putri).

\section{3) Problem in communication}

All the participants in this study had some degree of problem in communicating with other people. Therefore, self-injury becomes a form of expression of thoughts or feelings that cannot be conveyed verbally to others.

"The problem is that if I tell my emotional problem slowly, no one will understand. I cannot tell my family and my friends about my problem. That is why I sometimes burst my emotion out [through self-injury]. No one understands either. I just want to show, you know, this is my annoyance. You know my fault, this is my fault ..." (P2/Desi).

\section{4) The problem in getting along}

The participants have difficulty in getting along with peers. This problem 
makes participants experience social difficulties, especially when making friends.

"Sometimes, I am afraid to go to the crowd. I was scared because there was a voice in my mind telling me that I would never get along. So, when I am in a crowd, I am uncomfortable. Sometimes, I do not realize that I am crying" (P4/Auliya).

\section{5) Loneliness}

The participants experience loneliness because of difficulty in making friends. They felt that hardly anyone could understand their situation and that there was no one to share their opinions and feelings.

"My mom and dad are working early in the morning. They came back late at night. Usually, we get together late at night. Automatically during that time, I was at home alone. No friends either. So I was at home alone and no friends to chat with. Then what can I do? Sometimes I talk to my parents during dinner, but I feel that they did not listen to me at all?" (P3/Putri)

\section{Discussion}

The self-discrepancy experienced by adolescent self-injurers comes from their relationship with a dysfunctional family. Since childhood, children who grow up in dysfunctional families tend to develop long-term developmental problems because their needs are unmet (Allen, 2010). The family dysfunction in adolescent self-injurers in this study occurred in three ways: negative parenting styles, the inharmonious relationship between parents and children, and a less cohesive family.

Firstly, the parenting style adopted by parents has a significant impact on the mental and emotional development of children. Participants in this study grew up in an overprotective parenting style (P1/Arman) and neglective parenting (P2/Desi, P3/Putri, P4/Fadil, P5/Auliya,
\& P6/Rizki). Overprotective and neglected parenting are categorized as extreme parenting styles. They are risk factors contributing to triggering selfinjury in adolescents (Buresova, Bartosova, \& Cernak, 2015).

The parents who neglect their children generally make them feel abandoned. This situation creates selfdiscrepancy in children, making them feel that they are emotionally distant from their parents and do not receive enough attention. This represents neglected children versus well-cared children (selfdiscrepancy between actual/own versus ideal/own).

Sadness, disappointment, and annoyance towards parents are negative emotions felt by children who grow up in this neglected parenting. This situation is exacerbated when parents often make familial criticism, sarcastic expressions, and familial hostility, which are considered emotional abuse of parents to children (Child Welfare Information Gateway, 2018). Unhealthy relationships between parents and children and emotional disappointment are factors that trigger children to self-injure (Mortana, 2015).

Besides, excessive demands on academic achievement, which are not accompanied by sufficient parental attention to children, also contribute to self-injury. Children who feel that they have low or average intelligence but are asked to achieve high academic scores makes them feel under pressure. The discrepancy between the actual self and the ideal self, according to the parents, is a factor that encourages children to selfinjure (Brossard, 2018).

Arman's parents apply overprotective parenting, which according to Thomasgard, Metz, Edelbrock, \& Shonkoff (1995), consists of four factors, including careful supervision, separation problems, attachment to parents, and tight control. This type of parent adopts a parenting style that is too restrictive in 
everyday life and limits the child's activities with rigid family rules. As a result, the child does not have enough space to explore his or her interests and talents. If the child feels depressed and uncomfortable with this overly protective state, according to Buresova, Bartosova, \& Cernak (2015: 1107), there is a risk of leading to self-injury.

Secondly, the inharmonious relationship between parents and children is against the family culture in Indonesia, which requires children to obey and be devoted to their parents (Setiyani \& Windsor, 2018). When a child is rebellious and disobedient, he or she feels guilty for breaching social rules and values that have been embedded in society. Therefore, a self-discrepancy is formed between the actual self and versus ought/own.

The participants' big family believes that the children are obliged to be devoted to their parents. This situation represents self-discrepancy between impertinent versus filial piety (discrepancy between actual/own versus ought/other). At the same time, the participants showed a rebellious or disobedient attitude. For example, Arman let his hair long and refuse to cut it, which was opposed by his father. Also, Desi refused to tidy up the house and take care of her sick family members. This rebellious expression is an attitude of protest against their parents' parenting style. This situation represents self-discrepancy between disobedient/rebellious children versus obedient children (self-discrepancy between actual/own versus ideal/other). However, when other family members blamed them for their rebellious behaviour, they feel guilty. When guilt runs high, it becomes problematic. According to Sheehy, Noureen, Khaliq, Dhingra, Husain, Pontin, Cawley, \& Taylor (2019), this guilt is related to selfinjury.

Guilt for adolescents who selfinjure also emerges from bad sibling relationships. Tschan, Ludtke, Schmid, \& In-Albon (2019) stated that self-injurers have less warmth, less empathy, and more enmity with siblings. Besides, he or she also has weak emotional ties, does not care enough, and rarely gets along with his siblings. This study confirms the prior research, adding that despite their hostile attitude towards their siblings, adolescent self-injurers feel guilty about not getting along with their siblings. The discrepancy between the ideal self versus his actual self makes the participants vulnerable to sadness and guilt, leading to self-injury.

Thirdly, a less cohesive family associates with depressive symptoms and a lack of parent-child attachment (Rawatlal, Kliewer, \& Pillay, 2015). According to Fortune, Cottrell, \& Fife (2016), low family cohesion contributes to self-injury because it is a protective factor from deviant behaviour. The loss of protective factors has an association to propel children to self-injure.

Children also tend to model the behaviour of their parents. If parents do not provide enough space to express their opinions and express feelings, they tend to develop the same behaviour. When parents have less social contact with children, they develop difficulties in their social and communication skills (Arroyo, Nevarez, Segrin, \& Harwood, 2012). Besides, dysfunctional families that do not teach enough social skills make it difficult for children to get along well. Typically, children need daily social space, but when this attribute does not match the reality due to a lack of social skills and difficulties in getting along, self-discrepancy emerges.

The lack of social and communication skills is also a predictor that allows children to experience bullying (Fox \& Boulton, 2005). If a child becomes a victim of bullying, it will be easy for him to develop problematic behaviour, including self-injury (Karanikola, Lyberg, Holm, \& Severinsson, 2018). Furthermore, lack of social skills is a 
significant factor that causes social anxiety (Beidel, Rao, Scharfstein, Wong, \& Alfano, 2010). According to Chartrand, Sareen, Toews, \& Bolton (2012), social anxiety is associated with the emergence of suicidal ideation and self-injury.

Another problem that self-injurious adolescents often experience is being trapped in toxic relationships. In this study, female participants undergo an overprotective relationship, which leads to physical and emotional violence in dating. According to Wong, Wang, Meng, Phillips (2011), physical or emotional violence by intimate partners contributes to propel self-injury. Being stuck in an overprotective relationship keeps adolescents away from hanging out with their friends, which gradually makes them socially isolated. According to Ge, Yap, Ong, \& Heng (2017), social isolation correlates with loneliness and symptoms of depression. At the same time, there is a significant association between loneliness and self-injury (Muthia and Hidayanti, 2015).

Undergoing these unpleasant experiences triggers adolescents to compare themselves with others. To a certain degree, comparing oneself leads to a negative effect, making them feel unlucky and other people are in a better position than themselves. According to Gilbert, McEwan, Bellew, \& Mills (2009), this negative self-comparison correlates with depression, anxiety, stress, and selfinjury.

Another factor contributing to forming self-discrepancies among female adolescent self-injurers in this study was sexual violence, such as unwanted kissing, touching or rubbing her vital organs without her consent. This is in line with the study conducted by Swannell, Martin, Page, Hasking, Hazell, Taylor, \& Protani (2012) that sexual abuse and violence contributes to triggering self-injury in adolescents.

Sexual abuse and violence have a strong emotional impact on adolescents. If left untreated, it can result in emotional trauma and make adolescents have a low self-image, guilt (Feiring \& Taska, 2005), and self-hatred (Payne, Galvan, Willianms, Prusinski, Zhang, Wyatt, \& Myers, 2014). The discussion above can be summarized in figure 1. 


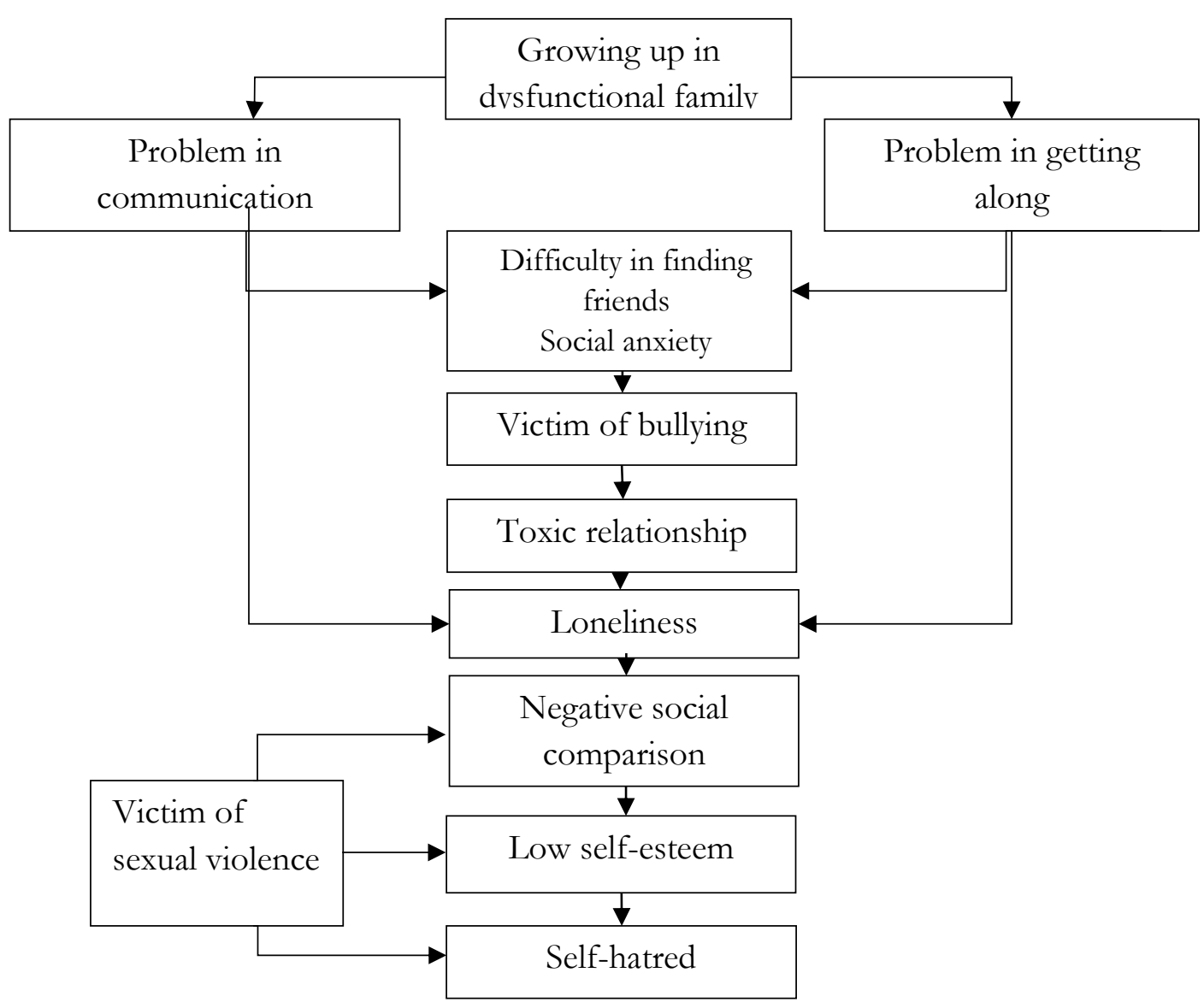

Figure 1. Formation of self-discrepancy in adolescents self-injurers

\section{Conclusion}

Based on the results of research and discussion, it concludes that the selfdiscrepancy experienced by adolescents starts from childhood when they grow up in dysfunctional families. The family was supposed to provide warmth, secure space, and teach essential communication and social skills, which the participants did not experience.

Furthermore, participants' social and communication skills are protective factors from bullying. When they are not maximally developed, participants are at risk of becoming victims of bullying in their social interactions. This runs the risk of making participants self-injure. Besides, other external factors, such as being trapped in a toxic relationship and sexual harassment experienced by participants, make it more vulnerable to self-injury.

The self-discrepancy experienced by participants results from their upbringing in dysfunctional families, unhealthy social interactions, and victims of sexual harassment. These experiences are perceived negatively by the participants, which leads to self-injury.

\section{Suggestion}

The results of this study can be used as a reference for intervention for psychologists, psychiatrists, counsellors, or mental health researchers to understand self-discrepancies in self-injurious adolescents. This is also can base on developing measuring instruments and intervention techniques for adolescent self-injurers. Then, researchers interested 
in conducting qualitative research on selfinjury should use interview techniques and observation and other data collection techniques to contribute to stronger data credibility.

\section{References}

Aji, R.F. (2010). Pengembangan Garuda (Garba Rujukan Digital) sebagai sumber rujukan karya ilmiah di Indonesia (The development of the Garuda (Garba Rujukan Digital) as a reference source for scientific work in Indonesia. Proceedings of the National Seminar on Information Technology Application, Indonesia, 1(1), 98-102.

Allen, D.M. (2010). How dysfunctional families spur mental disorders. California: ABC Clio.

Arroyo, A., Nevarez, N., Segrin, C., \& Harwood, J. (2012). The Association between parent and adult child shyness, social skills, and perceived family communication. Journal of Family Communication, 12, 249-264. http://dx.doi.org/10.1080/152674 31.2012.686941

Beidel, D.C., Rao, P.A., Scharfstein, L., Wong, N., \& Alfano, C.A. (2010). Social skills and social phobia: An investigation of DSM-IV subtypes. Behaviour Research and Therapy, 48, 992-1001.

http://dx.doi.org/10.1016/j.brat.20 10.06.005

Buresova, I. (2016). Self-harm classification system development: theoretical study. Review of Social Sciences, 4, 13-20. http://dx.doi.org/10.18533/rss.v1i 4.21

Buresova, I., Bartosova, K., \& Cernak, M. (2015). Connection between parenting styles and self harm in adolescence. Procedia: Social and
Behavioral Science, 171, 1106-1113. http://dx.doi.org/10.1016/j.sbspro .2015 .01 .272 .

Chartrand, H., Sareen, J., Toews, M., \& Bolton, J.M. (2012). Suicide attempts versus nonsuicidal selfinjury among individuals with anxiety disorders in a nationally representative sample. Depression and Anxiety, 29(3), 172-179. http://dx.doi.org/doi:10.1002/da.2 0882

Child Welfare Information Gateway. (2018). Parenting a child who has experienced abuse or neglect. Washington, DC: U.S. Department of Health and Human Services, Children's Bureau.

Crowe, S., Cresswell, K., Robertson, A., Huby, G., Avery, A., \& Sheikh, A. (2011). The case study approach. BMC Medical Research Methodology, 11, 100. https://doi.org/10.1186/14712288-11-100.

Estefan, G. \& Wijaya, Y.D. (2014). Gambaran regulasi emosi pada pelaku self-injury (Characteristics of emotional regulation in selfinjurers). Jurnal Psikologi, 12, 16-33.

Favazza, A. R. (1987). Bodies under siege. Self-mutilation in culture and psychiatry. London: John Hopkins University Press.

Fortune, S., Cottrell, D., \& Fife, S. (2016). Family factors associated with adolescent self-harm: a narrative review. Journal of Family Therapy, 38, 226-256.

https:/ / doi.org/10.1111/14676427.12119

Fox, C.L., \& Boulton, M.J. (2005). The social skills problems of victims of bullying: Self, peer and teacher perceptions. Journal of Educational Psychology, $\quad 75, \quad 313-328$. 
https://doi.org

/10.1348/000709905X25517

Ge, L., Yap, C.W., Ong, R., Heng, B.H. (2017). Social isolation, loneliness and their relationships with depressive symptoms: A population-based study. PLOS ONE 12, e0182145

Gilbert, P., McEwan, K., Bellew, R.,\& Mills, A.. (2009). The dark side of competition: How competitive behaviour and striving to avoid inferiority are linked to depression, anxiety, stress and self-harm. Psychology and Psychotherapy: Theory, Research and Practice, 82, 123-136. https://

https://doi.org/10.1348/14760830 8X379806

Ginsburg, K.R \& Kinsman, S.B. (2014). Guide adolescents to use healthy strategies to manage stress. New York: American Academy of Pediatrics.

Hall, G. S. (1904). Adolescence: Its psychology and its relation to physiology, anthropology, sociology, sex, crime, religion, and education. Englewood Cliffs, NJ: Prentice-Hall.

Higgins, E.T. (1987). Self-discrepancy: a theory relating self and affect. Pscycological Review, 3, 319-340. https://

https://doi.org/10.1037/0033-

295X.94.3.

Karanikola, M.N.K., Lyberg, A., Holm, A.L., \& Severinsson, E. (2018). The association between deliberate selfharm and school bullying victimization and the mediating effect of depressive symptoms and self-stigma: A systematic review. BioMed Research International, 1-36. https://doi.org/10.1155/2018/474 5791

Larkin, C., Di Blasi, Z. \& Arensman, E. (2014). Risk factors for repetition of self-harm: A systematic review of prospective hospital-based studies. PloS one, 9, 1-21.

Lazarus, R.S. \& Folkman, S. (1984). Stress, appraisal, and coping. New York: Springer

Liu, R. T., Cheek, S. M., \& Nestor, B. A. (2016). Non-suicidal self-injury and life stress: A systematic metaanalysis and theoretical elaboration. Clinical Psychology Review, 47, 1-14. https://doi.org/10.1016/j.cpr.2016 .05 .005 .

Loesch, M.A., (2015). My own worst enemy: Exploring factors that predict self-injury. (Unpublished Thesis). University of North Florida.

Lodebo, B.T., Moller, J., Larsson, J., \& Engström, K. (2017). Socioeconomic position and selfharm among adolescents: a population-based cohort study in Stockholm, Sweden. Child and Adolescent Psychiatry Mental Health, 11, 46-55.

https://doi.org/10.1186/s13034017-0184-1

Martin, G. \& Hack, J. (2018). Expressed emotion, shame, and non-suicidal self-injury. International Journal of Enviromental Research and Public Health, 15, 890. https://doi.org/10.3390/ijerph150 50890

Martorana, G. (2015). Characteristics and associated factors of non-suicidal self-injury among Italian young people: A survey through a thematic website. Journal of Behavioral Addictions, 4, 93-100. https://doi.org/10.1556/2006.4.20 15.001

McDonald, G., O’Brien, L., \& Jackson, D. (2008). Guilt and shame: Experiences of parents of selfharming adolescents. Journal of Child 
Health Care, 11, 298-310. https://doi.org/10.1177/13674935 07082759

Muthia, E.N. \& Hidayanti, D.S. (2015). Kesepian dan keinginan melukai diri sendiri (Loneliness and the desire to self-harm). Psympathic, Jurnal Ilmiah Psikologi, 2, 185 - 198.

Noviekayati, G.A.A. \& Mandas, A.L. (2016). Relationship between emotion-focused coping and tendency of self-poisoning in adolescents in Surabaya by gender and age. Proceedings of 31 st International Congress of Psychology, Japan, 1(12), 296-230.

https://doi.org/10.1002/ijop.1230

Payne, J. S., Galvan, F. H., Williams, J. K., Prusinski, M., Zhang, M., Wyatt, G.E., \& Myers, H.F. (2014). Impact of childhood sexual abuse on the emotions and behaviours of adult men from three ethnic groups in the USA. Culture, Health \& Sexuality, 16, 231-245.

https://doi.org/10.1080/13691058. 2013.867074

Rawatlal, N., Kliewer, W., \& Pillay, B. J. (2015). Adolescent attachment, family functioning and depressive symptoms. South African Journal of Psychiatry, 21, 80-85. https://doi.org/10.7196/SAJP.825 2

Reis, M., Tome, G., Ramiro, L., \& Gaspar, S. (2020). Understanding risk factors associated with self-harm behavior in adolescents -HSBC. International Journal of Education Humanities and Social Science, 3, 79-92.

Santrock, J.W. (2011). Life span development. Jakarta: Erlangga

Setiyani, R. \& Windsor, C. (2019). Filial piety: From the perspective of Indonesian young adults, Nurse
Media Journal of Nursing, 9, 1, 46-57. https://doi.org/10.14710/nmjn.v9i 1.21170

Shapiro, S. (2008) Addressing self-injury in the school setting. The Journal of School Nursing, 24, 124-130. https://doi.org/10.1177/10598405 12344321

Sheehy, K., Noureen, A., Khaliq, A., Dhingra, K., Husain, N., Pontin, E.E., Cawley, R., \& Taylor, P.J. (2019). An examination of the relationship between shame, guilt and self-harm: A systematic review and meta-analysis. Clinical Psychology Review, 73, 101779. https://doi.org/10.1016/j.cpr.2019 .101779 .

Simeon, D., \& Favazza, A. R. (2001). Selfinjurious behaviors: Phenomenology and assessment. In D. Simeon, \& E. Hollander (Eds.), Self-injurious behaviors: Assessment and treatment. Washington, DC: American Psychiatric Publishing.

Swannell, S., Martin, G., Page, A., Hasking, P., Hazell, P., Taylor, A., \& Protani, M. (2012). Child maltreatment, subsequent nonsuicidal self-injury and the mediating roles of dissociation, alexithymia and self-blame. Child Abuse \&o Neglect, 36, 572-584. https://doi.org/10.1016/j.chiabu.2 012.05.005

Thomasgard, M., Metz, W. P., Edelbrock, C., \& Shonkoff, J. P. (1995). Parentchild relationship disorders. Part I. Parental overprotection and the development of the Parent Protection Scale. Journal of Developmental and Behavioral Pediatrics, 16, 244-250. https://doi.org/10.1097/00004703 $-199508000-00006$

Tschan, T., Ludtke, J., Schmid, M., \& InAlbon, T. (2019). Sibling 
relationships of female adolescents with nonsuicidal self-injury disorder in comparison to a clinical and a nonclinical control group. Child and Adolescent Psychiatry Mental Health, 13:15.

https://doi.org/10.1186/s13034019-0275-2

VanDerhei, S., Rojahn, J., Stuewig, J., \& McKnight, P.E. (2014). The effect of shame-proneness, guiltproneness, and internalizing tendencies on nonsuicidal selfinjury. Suicide and Life-Threatening Behavior, 44, 317-330. https://doi.org/10.1111/sltb.12069

Wilkinson, P. (2013). Non-suicidal selfinjury. European Journal of Child and Adolescent Psychiatry. 22, S75-S79. https://doi.org/10.1007/s00787012-0365-7.

Wong, S.P.Y., Wang, C., Meng, M., \& Phillips, M.R. (2011). Understanding self-harm in victims of intimate partner violence: A qualitative analysis of calls made by victims to a crisis hotline in China. Violence Against Women 17, 532-544. https://doi.org/10.1177/10778012 11404549. 